\title{
An Explanation of the Underdevelopment of China's Service Sector from the Perspective of Demand
}

Wenjing Fan ${ }^{1}$, Jiadong Pan $^{2}$, Minghai Zhou ${ }^{3}$

${ }^{1}$ School of Economics and Management,Hangzhou Normal University, Hangzhou,

China; ${ }^{2}$ Zhejiang Institute of Administration, Hangzhou, China; ${ }^{3}$ School of Economics and GEP-China, University of Nottingham Ningbo China, Ningbo, China

Corresponding author:

Wenjing Fan, School of Economics and Management, Hangzhou Normal University Address: No.2318, Yuhangtang Rd, Hangzhou, Zhejiang 311121, China.

Email: wenjingfan@hznu.edu.cn 


\title{
An Explanation of the Underdevelopment of China's Service Sector from the Perspective of Demand
}

\begin{abstract}
The share of the service sector in China is significantly lower than that in most countries at the same level of income. Figures reveal that an insufficiency in both consumer and producer demand may be one of the reasons. We find that the demand insufficiency mainly stems from high consumer preferences for saving and China's export-oriented trade structure. These excessive saving tendencies limit consumer demand for service products and thus hamper the development of consumer services in China. The rapid development of the processing trade also impedes the interrelation between the domestic manufacturing and service industries, reduces the effective demand for local producer services from the manufacturing industry, and ultimately restricts the growth of the producer service industry in China.
\end{abstract}

Key words: service sector; final demand; intermediate demand

JEL: C10; O14

\section{Introduction}

One of the most important trends in the new century is the increasing role of the service sector in the global economy. According to the World Bank's World Development Indicators (WDI), the average share of the service sector in gross domestic production (GDP) increased to $74 \%$ in high-income countries in 2014. Even in low- and middleincome countries in the same year, the service sector share represented about $55 \%$ of GDP. ${ }^{1}$ Therefore, the service sector has become the engine of economic growth in most countries.

Following economic reform and its opening to the global economy, China's service economy has made great progress in pace with the booming national economy and the improvement in marketization. The share of the service sector in value-added terms went from $33.6 \%$ to $47.8 \%$ over the period of 1996 to 2014 , an increase of 
$14.2 \%{ }^{2}$ However, according to the World Bank, in 2014, the share of China's service sector in GDP was significantly lower than most countries at the same income level, and even lower than the average level (55\%) for low- and middle-income countries (as shown in Figure 1). This suggests that the service sector in China remains stubbornly underdeveloped compared with the growth rate and income levels for comparable economies, a situation which has been termed the "service sector and economic development deviation puzzle" (Zheng, Zhang and Wang 2011). Recently, Wu (2015) presented a review of service sector development in China and concluded that while the sector has recently emerged as the dominant contributor to economic growth, it "continues to lag behind comparable economies at a similar stage of economic development".

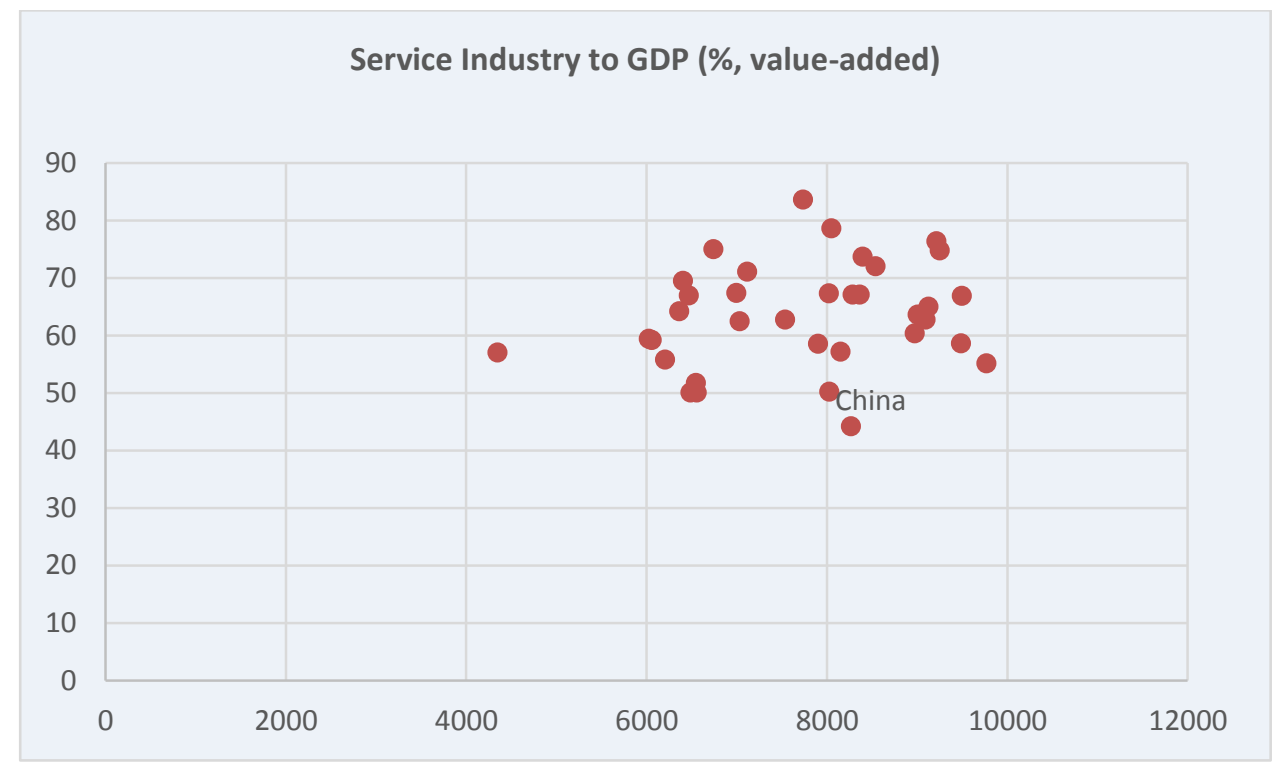

Figure 1 Share of service sector and per capita GDP in different countries

Source: World Bank "World Development Index 2015". With the exception of Gabon, the share of the service sector in China is the lowest among countries with per capita GDP between $\$ 4,000$ and $\$ 10,000$.

The so-called deviation puzzle has promoted much debate in the field of economics as economists attempt to explain the phenomenon from several perspectives. For instance, Jiang and $\mathrm{Li}$ (2004) found that personal income and the level of urbanization had positive correlations with the proportion of the service sector in GDP, 
which is consistent with the experience of most developed countries. Alternatively, Wang, Zhang and Bai (2007) examined the impact of the size of government and the rule of law on the growth of the service sector. They showed that while there is a significant positive correlation between the qualities of contracting institutions with the proportion of the service sector in GDP, there is a significant negative correlation between the proportion of service sector with government expenditure. Elsewhere, Zheng, Zhang and Wang (2011) tested Baumol's cost disease (or the Baumol effect) hypothesis using data from the Yangtze River Delta and found that labour productivity growth in the service industry was driven by capital investment and the "development deviation puzzle" indeed stemmed from "manufacturing cost disease." Lastly, Cheng (2013) argued that the underdevelopment of the service sector in China was mainly the result of the less specialized division of labour, a lack of innovation, and inadequate demand, but did not test his arguments using empirical analysis.

Several empirical features of the development of the service industry in China suggest that an insufficiency of demand, which is an area largely neglected by past studies, may explain the underdevelopment of China's service sector.

Using the input-output table for China, the US, and India in $2011^{3}$, we can calculate the demand structure ${ }^{4}$ of the service sector in the three countries separately. The share of consumption demand ${ }^{5}$ in most service industries in China is about $30 \%$, and the average share of consumer consumption in service industries is $34.42 \%$ (see Appendix Table A1). In contrast, the share of consumption demand for most service industries in the US exceeds 50\%, and the average proportion is $58.86 \%$, which is 24 percentage points higher than that in China. Even in India, the share of consumption demand for most service industries is also roughly $50 \%$, with an average of $53.79 \%$, and still 20 percentage points higher than that in China. Specifically, the final consumption 
demand for wholesale and retail services in China is $12.38 \%, 54.25 \%$ in the US, and $34.61 \%$ in India, while final consumption demand for financial intermediary services is $23.27 \%$ in China, $40.15 \%$ in the US, and $32.04 \%$ in India. Therefore, from the perspective of the demand structure for services, China's final service demand is not only much lower than that in high-income countries like the US, but also in low-income countries such as India. Given the significant role of consumption demand in the development of service industries, the insufficiency of consumption demand for services is an important factor restricting the development of China's service industries.

Simultaneously, the share of service inputs ${ }^{6}$ in manufacturing industries (or the servitization level) in China is also much lower than that in either the US or India. The 2011 input-output table shows that the average proportion of service input in 19 industrial industries in China is $16.11 \%$, while the proportion of that in the US and India is $33.62 \%$ and $27.59 \%$ respectively (see Appendix Table A2). Specifically, the shares of research and development (R\&D) and business services, computer-related services, and educational services, which are the most knowledge-intensive parts of the industrial value chain, account for $0.35 \%, 2.64 \%$, and $0.10 \%$ of total intermediate input in manufacturing industries in China. In comparison, these shares in the US are $1.12 \%$, $8.80 \%$, and $0.37 \%$ respectively, which are all three times greater than that in China. Thus, the lower share of intermediate demand in the manufacturing sector is another important reason for the underdevelopment of China's service sector.

To explore this mechanism more thoroughly, we focused on this demand perspective. Combining income elasticity theory, industrial relevancy theory, and the characteristics of China's economic development, we formulated four hypotheses to provide the reasons for the insufficient demand for services in China. Our analyses indicate that the consumption behaviour of Chinese consumers, China's export-oriented 
pattern of trade, and the large proportion of state-owned enterprises (SOEs) in China might serve as obstacles hindering the demand for services. The main objective of this paper is to test these hypotheses and identify the endogenous factors that influence the current and future growth of China's service sector.

To do this, we divided demand into consumer and producer demand, and then identified the specific influencing factors for each type of demand that limits the development of service industry. Our empirical tests suggest that the demand insufficiency mainly stems from Chinese consumers' preference for saving and China's export-oriented trade structure. The excessive saving tendencies limit consumer demand for service products and hamper the development of consumer services. Simultaneously, the rapid development of processing trade hinders the interrelation between the domestic manufacturing and service industries, reduces the effective demand for local producer service from the manufacturing industry, and ultimately limits the growth of producer services.

The remainder of the paper is organized as follows. Section 2 provides a brief review of the related literature. Section 3 proposes the four theoretical hypotheses concerning the fundamental factors affecting the development of China's service sector from a demand perspective. Section 4 indicates the data resources and indictors for different variables. Section 5 tests the theoretical hypotheses using provincial data. Section 6 discusses the importance of our findings and Section 7 concludes.

\section{Literature review}

There is a basic law of industrial structure evolution in developed countries. With the development of economy, the labour force shifts from the primary industry to the secondary and tertiary industries, and the share of the industry and service sectors in the economy increases (Clark 1940). Since the middle of 20th century, service industry has 
become the dominant sector in almost all the developed countries, which was termed as "the service economy" or "economic servitization" (Wolf 2005). Therefore, "economic servitization" is not a new subject and the existing literature related to our paper is voluminous. Accordingly, we provide here a brief review of the studies on the evolution rules and mechanisms of the service sector.

To begin with, early studies of the service economy focused on structural change. Fisher (1939) initially proposed the classification of the three sectors, namely, the extraction of raw materials (primary), manufacturing (secondary) and services (tertiary), and subsequently, Clark (1940), Kuznets (1953) and Chenery (1960) observed the evolution of these industries, especially the rising share of employment in services. Bell (1974), Galbraith (1967), Gershunny (1978), and Walker (1985) later proposed different theories to explain the growth of the service sector while still emphasizing the key role of manufacturing. These researchers hold that the growth of the service sector is only the result of a change in the production process. Beyers and Lindahl (1996) also showed that the independence of service activities represents only a change in the way that industrial production is organized, which does not indicate the so-called development of service economy.

There are four relatively complete theoretical explanations in the recent literature concerning the rising share of the service sector, i.e., income elasticity theory, cost disease model, externalization theory, and the international division of labour theory, each of which we discuss in detail in the following sections.

First, based on Engel's law, Clark (1940) first explained the expansion of the employment share of the service sector from the perspective of final demand. He argued that the increase in the proportion of the service sector was mainly due to consumption demand because consumer demand for services has a higher income elasticity than for 
industrial and agricultural products. Kuznets (1953) also argued that the income elasticity of service demand is greater than one, so that the share of demand for services grows as income levels increase.

Subsequently, Baumol (1967) proposed a nonequilibrium growth model in which the productivity of the service sector was stagnant or nonprogressive compared with the manufacturing industry, and that the share of employment in the service sector should then increase to maintain a balance between the manufacturing and service sectors. Soon after, Fuchs (1968) revealed that low productivity in the service sector was the main reason for its increase in the proportion of employment. This finding provided empirical support for Baumol's theory. Although theoretical and empirical studies have subsequently shown that the cost disease model does well in explaining the changes in industrial structure before the 1970s, human capital and technology-intensive producer services have long dominated the service sector in developed countries since the 1980s, all of which represent higher productivity and are therefore "progressive" (Schettkat and Yocarini 2006). Therefore, the cost disease model can no longer fully explain the rising share of the service industry.

After the 1980s, several scholars, including Grubel and Walker (1989), and Coffey and Bailly (1991), concluded that the fastest growing services are the intermediary services for enterprises. As a result, most researchers began to explain the development of the service industry from the perspective of the division of labour and the externalization of services. Grubel and Walker (1989) analysed data from the Canadian service sector and revealed that the actual output of consumer services did not increase, and the share of government services declined. Their study also showed that the steady growth of the service sector was mainly from the development of producer services, i.e., to meet the intermediate demand from other industries. Francois (1990) 
also concluded that the services that had grown most dramatically since the 1950 s were producer or intermediate services. Using a model to explore the relations between producer services, market expansion, and the division of labour, he highlighted the role of services as a complement rather than a substitute for the manufacturing process (Guerrieri and Meliciani 2005). Coffey and Bailly (1991) argued that innovation and the differentiation of services and products made services become increasingly important. ${ }^{7}$ Furthermore, the growth in firm scale and the extension of industrial chains lead to a significant increase in internal management and coordination (Liu, Rui and Yao 2010), which contribute to the rapid growth of producer services.

The last of the four theories holds that the rapid development of the service industry in developed countries is a manifestation of the global division of labour. For instance, Lee (1984) showed that from the perspective of global economic integration, the service sector in the global economy might be concentrated in just a few countries and regions. In doing so, it forms an international professional service centre, so that the very high share of the service sector in developed countries merely reflects the performance of this international division of labour. Chen (2004) also argued that in the context of the current international division of labour, some countries have taken their comparative advantages to focus on the production of services and transfer their industrial production to other countries, resulting in a rapid increase in the proportion of services in their own country.

As discussed in the Introduction, contrary to the servitization trend in most countries, the share of the service sector in China has been growing at a steady but low rate relative to its rapid economic growth, a situation termed the "service sector and economic development deviation puzzle" (Zheng, Zhang and Wang 2011). China was a pure agricultural economy after established the new government in 1949. In 1953, under 
the planed economic system, Chinese government carried out a lot of industrialization policies, which prompted the development of manufacturing industry and established a complete industrial structure. With the implementation of the reform and opening up policy China's economy has started to take off and people's living standard has increased dramatically. China is an upper middle-income country now, but the share of its service sector is lower than most low-income countries. Researchers have explained this puzzle from several different perspectives, including statistical discrepancy, traditional conceptions and policies, and an unbalanced trade pattern.

With respect to the first perspective, $\mathrm{Xu}$ (2000) pointed out that statistical omissions can lead to the serious underestimation of the service industry in China. However, Jiang and Li (2004) suggested that even if we adjust the data and solve the omission problem, the service industry in China will still be relatively smaller than that in other countries at a similar income level.

The second perspective argues that traditional conceptions, institutions, and policies are widely acknowledged factors affecting the growth of the service sector in China. Under the traditional economic system, each enterprise is an island, with almost all services internalized, while service externalization and marketization significantly lag behind their equivalents in other countries (Cheng 2008). The administrative monopoly of the service industry precludes opportunities for many small- and mediumsized enterprises to enter the market, which leads to a lack of competition and stagnant efficiency in most service industries (Peng 2001; Jiang and Li 2004). Further, in China, the urban-rural dual structure and the household registration system hinder the transfer of the labour force from agriculture to the service industry, which likewise affects its growth (Lu and Liu 2006). 
The third perspective argues that the export-oriented trade pattern in China has also hindered the growth of the service sector in China by outsourcing producer services to multinational companies in developed countries. In evidence, $\mathrm{Lu}$ and $\mathrm{Liu}$ (2006) analysed the industrial development model of the eastern coastal areas of China and found that the export-oriented trade pattern effectively promoted the rapid growth of the local economy, but commensurately reduced the demand for local producer services. Foreign parent companies only outsource their assembly lines to China and retain the high value-added service parts in their own countries, such as $R \& D$, technical services, legal services, market research, and sales channels, which seriously impedes the interaction between domestic manufacturing and service industries and hinders the development of the local service industry. Jiang and Liu (2010) also suggested that the underdevelopment of the service sector in China was mainly because of the domination of its trade structure by processing trade, which separates the industrial relation between manufacturing and producer services and in doing so restricts the development of local producer services. Recently, Chen (2013) attempted to examine three important mechanisms that are crucial to the development of a nation's service sector, the specialized division of labour, innovation, and demand-induced mechanisms. He suggested that the lower level of the specialized division of labour is the main reason for China's underdeveloped service sector.

In conclusion, studies on the rising share of service industry in developed countries mainly focus on the objective laws of industrial evolution, the difference in productivity between the manufacturing and service sectors, the division of labour and the externalization of services, as causes for the rising share of the service sector in developed countries at different stages of development. However, China is a large developing country in a transition period, and its development and economic patterns 
differ from those of developed countries. For this reason, we cannot easily apply the theories formed in developed countries to explain the underdevelopment of the service industry in China. At present, the explanations for the underdevelopment of the service industry from Chinese researchers have emphasized statistical discrepancy (Xu 2000; Jiang and Li 2004), traditional conceptions and policies (Cheng 2008; Lu and Liu 2006), or other exogenous factors (Cheng 2013), and rarely attached importance to the demand side, which could potentially interpret the underdevelopment endogenously.

Our analysis from the demand perspective is related to several papers, such as Lu and Liu (2006), Jiang and Liu (2010), and Cheng (2013). Lu and Liu (2006) and Cheng (2013) highlighted the importance of the demand side to the development of China's service sector and proposed theoretically that the processing trade might hinder the linkage between manufacturing and the service industry. However, neither work carried out specific empirical tests to validate their hypothesis. Our paper systematically explores the endogenous factors negatively influencing the development of China's service sector from the demand perspective and uses provincial-level data to carry out empirical tests. Jiang and Liu (2010) performed simple empirical analysis to test the relationships between the development of producer services and processing trade, taking the proportion of processing trade to GDP as a proxy of trade structure, which could only reflect the development of trade rather than trade structure. Our paper improves the measurement of trade structure with more precise indicators and we conduct more tests to solve the potential endogeneity problems.

Another novel feature of our paper is that we employ savings as a key variable to explain the underdevelopment of China's service sector. High consumer preferences for saving in China have been extensively studied in different areas, although they are rarely mentioned in the literature to explain the underdevelopment of China's service 
industry. Our study shows that the high consumer preferences for saving might be the main factor affecting the development of China's service sector.

\section{Hypotheses}

The comparisons of input-output tables between China, US and India ${ }^{8}$ shows that the insufficient consumption demand for services and the low degree of manufacturing servitization are external reasons obstructing the growth of China's service sector. What are the influencing factors initiating this demand insufficiency? Given China's economic and industrial development, this section analyses this question from the perspective of final and intermediate demand, and proposes four hypotheses to be tested.

According to the theory of income elasticity, the income elasticity of service products is greater than that of either industrial or agricultural products. As Income rises, the demand for goods tends to rise less rapidly than the demand for services; hence, the importance of services in the economy will rise (Fuchs 1968). In other words, the higher the level of income is, the greater the share of the service sector. However, the relation between income level and service growth in China may not follow this generality.

Influenced by the ideology of Confucianism, most Chinese are frugal, which results in the fact that most of the income growth in a family goes to saving account except consuming life necessities, nearly all of which are agriculture and manufacturing products (Ye 2008). In other words, ordinary Chinese people are not accustomed to consuming non-material service products. Simultaneously, Chinese are mostly future oriented, which increases their saving motivation for their children's education or a better house in the future. These consumption behaviours result in an extraordinarily high savings rate in China and the low consumption of services such as travelling, entertainment, and sports. Therefore, the common assumption that service demand is more income elastic may not apply in China. Overall, we believe that, if we control for 
the level of income, the higher the savings rate in a region, the lower the final demand for its services, and the lower the share of its service sector.

H1: With the rise of personal income in a region, the share of the service sector will simultaneously increase;

H2: The savings rate will negatively correlate with the level of final service demand and the level of service development.

The data analysis also shows that the insufficiency of intermediate demand resulting from the low degree of manufacturing servitization is another important factor affecting the growth of the service sector in China. Thus, what are the fundamental factors that have led to the inadequate demand for intermediate services? Viewed from the perspective of the pattern of China's economic development since the Reform and Opening-up of the 1970s, we speculate that foreign trade based on processing trade and the large proportion of SOEs may be the main factors influencing the insufficiency of intermediate demand.

First, the foreign trade pattern based on processing trade has separated the industrial connection between the manufacturing and service sectors in China, and correspondingly hindered the demand for intermediate services by the manufacturing sector. The theory of industrial relevancy holds that the increasing demand for services through the increase in intermediate inputs will spontaneously promote the development of modern service industries (Grubel and Walker 1989). This should hold if supply and demand in the industrial chain are unaffected by obvious external factors. However, the development of China's manufacturing sector has mainly depended on the development of an export-oriented economy in recent years, which has influenced the connection between local manufacturing industries and services. In most respects, the Original Equipment Manufacturer production and processing trade separates domestic 
manufacturers from R\&D design, brand management, marketing, and other intermediate services; thus, the home country's multinational corporations control these services. In turn, this reduces the market demand for domestic intermediate services and hinders the development of local service industries.

\section{H3: The share of processing trade will negatively affect the development of a} region's service sector.

Second, the large share of state-owned enterprises in China decreases the overall demand for intermediate services by manufacturing enterprises, with SOEs owned by governments, but operated by managers, resulting in the principal-agent problem. As an agent, the managers motivated to act in their own interests, such as expansion and diversification, which are key for managers in SOEs. The principal-agent problem leads to the alienation of the objective function, where these managers are concerned more about the expansion of the firm rather than profit maximization (Bai and $\mathrm{Xu} 2005$ ). Therefore, SOEs have greater motivation to expand the scale of their businesses than increasing investment in the service sector to improve efficiencies, which decreases their demands for intermediate services. Meanwhile, SOEs prefer diversification, which leads to the greater internalization of intermediate services and decreases the demand for external services on the market, and ultimately hinders the development of the service sector. Therefore, our second hypothesis is as follows:

H4: The proportion of SOEs will negatively affect the development of a region's service sector. 


\section{Data and Methodology}

\section{Econometric model and variables}

We use provincial panel data in China from 2008 to 2014 to test our hypotheses. We construct an empirical model to investigate the correlations between the development of the service sector and the influential factors from the perspective of demand. The basic model is as follows:

$$
\text { Serv }_{i t}=+{ }_{1} \text { Saving }_{i t}+{ }_{2} \text { Income }_{i t}+{ }_{3} \text { Export }_{i t}+{ }_{4} \text { State }_{i t}+X_{i t}+{ }_{i t}
$$

In the equation, subscript $i$ denotes the province and $t$ denotes time. Serv $v_{i t}$ is the dependent variable, which represents the development of the service sector, and for which we specify service output per capita ${ }^{9}$ as a proxy. Saving it $_{\text {is }}$ the average saving rate in a specific region, which we calculate using per capita disposable income minus per capita consumption expenditure. Income $_{i t}$ represents the income level in a region, for which we specify per capita disposable income. Export $t_{i t}$ denotes the foreign trade structure of a region, i.e., the proportion of processing trade. In fact, the enterprises engaged in processing trade exports are mainly foreign enterprises. Therefore, we use the proportion of exports from foreign investment enterprises in total exports to represent the level of processing trade development. ${ }^{10}$ We deflate all the level values in services, income, savings and exports, so they are netted for inflation. State ${ }_{i t}$ is the proportion of SOEs in a region, for which we use the proportion of numbers of stateowned industrial enterprises to total number of industrial enterprises as a proxy. The ratio of the sales volume of SOEs is also a good representation of the development level of the state-owned economy. Therefore, we use this as a substitute measure of the proportion of numbers. Finally, $\mathrm{X}$ are control variables, which given the significant role of labour inputs in the service sector and regional marketization, we include the share of 
employment in the service sector to total population and the comprehensive marketization index into our model. In terms of our a priori predictions, we expect the coefficients on $\beta_{2}, \beta_{3}$, and $\beta_{4}$ to be negative and those on $\beta_{1}$ to be positive.

\section{Data sources and descriptive statistics}

Data for service output, savings, income, export, the SOEs, labour in service sector are taken from China's Statistical Yearbooks from 2009 to 2015 published by the National Bureau of Statistics of China. The data on the marketization index are from the 2011 and 2016 NERI Index of Marketization in China's Provinces Reports (Wang, Fan and Yu 2016). As some data for Tibet and Ningxia are unavailable, our final sample comprises 29 provinces, municipalities, and autonomous regions. The time interval is from 2008 to 2014, with 203 observations in total. Table 1 provides some selected summary statistics.

Table 1 Descriptive statistics of key indictors

\begin{tabular}{cccccc}
\hline Variables & Mean & Std. Dev. & Min. & Max. & Obs. \\
Service output per capita (in added-value) & 17225 & 13346 & 4594.9 & 77263 & 203 \\
Savings per capita & 6287.6 & 2506.2 & 2660.8 & 14814 & 203 \\
Income per capita & 21093 & 7077.2 & 10969 & 48841 & 203 \\
Export structure (\%) & 16.781 & 11.836 & 0.0419 & 44.560 & 203 \\
Share of SOEs in number (\%) & 10.383 & 7.1629 & 1.1342 & 28.350 & 203 \\
Share of SOEs in sales (\%) & 37.104 & 18.118 & 10.402 & 80.203 & 203 \\
Labour in service sector (to total population) & 0.0604 & 0.0350 & 0.0311 & 0.2425 & 203 \\
Marketization & 6.0560 & 1.6913 & 2.5300 & 9.9500 & 203 \\
\hline
\end{tabular}

In empirical analysis, we firstly use fixed effects and random effects to estimate the model. To avoid potential endogeneity problems and ensure the robustness of our model, we also provide the results of IV regression and GMM regression. To find more useful results, we do tests with the data of specific service industries. 


\section{Empirical results}

China's economic development is uneven across its different regions. Given the economic geography of China with its concentration in the coastal provinces, it is appropriate to use fixed effects to estimate the model. We firstly present the fixed effects and the random effects regression results. To avoid potential problems with endogeneity and ensure the robustness of our model, we provide the results of IV regression and GMM regression (see Table 2). Secondly, we take further tests on the role of processing trade and the SOEs in the development of service sector (see Table 3). To find more useful results, we also do tests with the data of specific service industries (see Table 4).

\section{Regression results and analysis}

In first two columns of Table 2, we present the basic estimation results with fixed effects and random effects. Hausman test indicates that, we should choose the results estimated with fixed effects. As shown in the first column of Table 2, Income per capita positively correlates with the development of the service sector, and the coefficient is significant at the level of $1 \%$, which is consistent with the general law of industrial evolution. At the same time, Savings per capita has a negative correlation with service output per capita, with a coefficient of -0.982 and significant at the $1 \%$ level. This is also in line with our theoretical expectations, which means that the higher the average savings in a region, the lower the level of development of its service sector. As discussed, many Chinese prefer to save after meeting their necessity for living, rather than consuming more services as people in most developed countries do (especially in the US). Therefore, our theoretical hypotheses on factors affecting consumption services are true. 
On the factors affecting intermediate services, as shown in the second column of Table 2, the correlation between the level of regional processing trade and the development of the service sector is negative, with an estimated coefficient of -89.29 , which is significant at the $1 \%$ level. This is also in line with theory, i.e., the higher the level of processing trade in a region, the lower the level of its service sector development. Although processing trade has effectively promoted the growth of the local economy, it has hindered the local industry interrelation between manufacturing and services, reduced the effective demand for local producer (or intermediate) services from the manufacturing sector, and negatively affected the overall growth of the service sector. This result also indirectly proves the key role of intermediate input services in the overall growth of the modern service sector.

In addition, there is a significant positive correlation between the proportion of SOEs and the level of service sector development, with an estimated coefficient of 345.6. This suggests that a greater share of the state-owned economy in a region does not impede the development of the local service sector. One possible interpretation is that to restructure SOEs, the Chinese government has pursued various policies that require SOEs to take full responsibility for their own profits and losses, and to operate in a market-oriented manner. Therefore, the intermediate service input demand and service externalization level of the SOEs will not be significantly lower than that of private enterprises. Simultaneously, according to Barcet, Bonamy and Mayere (1983), a firm's demand for intermediate services is positive correlated with firm size; therefore, the demand for intermediate services from SOEs exceeds that from private enterprises because of the difference in scale. When we substitute firm size for the share of SOEs in our regression model, we also obtain a positive correlation with a region's service development (See Table 3). 
Table 2 Main estimation results

\begin{tabular}{|c|c|c|c|c|c|c|}
\hline \multirow{3}{*}{$\begin{array}{l}\text { Independent } \\
\text { variables }\end{array}$} & \multicolumn{6}{|c|}{ Dependent variable } \\
\hline & \multicolumn{6}{|c|}{ Service output per capita } \\
\hline & $\mathrm{FE}$ & $\mathrm{RE}$ & $\mathrm{FE}$ & RE & IV & GMM \\
\hline \multirow{2}{*}{ Income per capita } & $1.024^{* * * *}$ & $0.888^{* * * *}$ & $1.129^{\text {**** }}$ & $0.945^{* * * *}$ & $0.980^{* * * *}$ & $0.934^{* * * *}$ \\
\hline & $(0.000)$ & $(0.000)$ & $(0.000)$ & $(0.000)$ & $(0.000)$ & $(0.000)$ \\
\hline \multirow[t]{2}{*}{ Saving per capita } & $-0.982^{* * *}$ & $-0.904^{* * *}$ & $-0.953^{* * *}$ & $-0.874^{* * *}$ & $-1.028^{* * *}$ & $-0.892^{* * *}$ \\
\hline & $(0.000)$ & $(0.000)$ & $(0.000)$ & $(0.000)$ & $(0.000)$ & $(0.000)$ \\
\hline \multirow[b]{2}{*}{ Export Structure } & $-89.29^{* * *}$ & $-62.30^{* * *}$ & $-63.44^{* * *}$ & $-49.49^{* *}$ & -36.46 & -27.42 \\
\hline & $(0.000)$ & $(0.003)$ & $(0.003)$ & $(0.021)$ & $(0.168)$ & $(0.289)$ \\
\hline \multirow{2}{*}{ Share of SOEsl } & $345.6^{* * *}$ & $189.0^{* * *}$ & & & $316.8^{* * *}$ & $329.2^{* * *}$ \\
\hline & $(0.000)$ & $(0.003)$ & & & $(0.000)$ & $(0.000)$ \\
\hline \multirow[b]{2}{*}{ Share of SOEs 2} & & & $137.2^{* * *}$ & $85.42^{* * *}$ & & \\
\hline & & & $(0.000)$ & $(0.001)$ & & \\
\hline Labour in service & $97228^{* * *}$ & $170179^{* * *}$ & $72950^{*}$ & $162255^{* * *}$ & $138053^{* * *}$ & $147370^{* * *}$ \\
\hline sector & $(0.001)$ & $(0.000)$ & $(0.012)$ & $(0.000)$ & $(0.000)$ & $(0.000)$ \\
\hline \multirow[b]{2}{*}{ Marketization } & $1970.0^{* * *}$ & $2380.0^{* * *}$ & $1941.0^{* * *}$ & $2288.0^{* * *}$ & $1288.9^{* * *}$ & $1105.4^{* * *}$ \\
\hline & $(0.000)$ & $(0.000)$ & $(0.000)$ & $(0.000)$ & $(0.003)$ & $(0.007)$ \\
\hline \multirow[b]{2}{*}{ _cons } & $-18083.3^{* * * *}$ & $-21426.7^{* * *}$ & $-20794.4^{* * *}$ & $-23217.8^{* * *}$ & & \\
\hline & $(0.000)$ & $(0.000)$ & $(0.000)$ & $(0.000)$ & & \\
\hline$N$ & 203 & 203 & 203 & 203 & 145 & 145 \\
\hline$R^{2}$ & 0.946 & 0.941 & 0.947 & 0.942 & 0.941 & 0.941 \\
\hline$F$ & $\begin{array}{c}487.48^{* * *} \\
(0.000)\end{array}$ & $\begin{array}{l}3031^{* * *} \\
(0.000)\end{array}$ & $\begin{array}{c}497.38^{* * *} \\
(0.000)\end{array}$ & $\begin{array}{l}3077^{* * *} \\
(0.000)\end{array}$ & & \\
\hline Hausman & \multicolumn{2}{|c|}{$(0.009)$} & \multicolumn{2}{|c|}{$(0.000)$} & & \\
\hline$K P L M$ & & & & & $\begin{array}{c}23.715^{* * *} \\
(0.000)\end{array}$ & $\begin{array}{c}23.715^{* * *} \\
(0.000)\end{array}$ \\
\hline$K P$ Wald $F$ & & & & & $111.925^{* * *}$ & $111.925^{* * *}$ \\
\hline Hansen J & & & & & $2.658^{* * *}$ & $2.658^{* * *}$ \\
\hline
\end{tabular}


Notes:(1) The figures in parentheses are P-values. ${ }^{* * *},{ }^{* *}$, and ${ }^{*}$ indicate the coefficient is significant at the $1 \%, 5 \%$ and $10 \%$ levels, respectively. (2) Share of SOEs1 is calculated in number of enterprises; Share of SOEs2 is calculated in sales volume. (3) The F statistic in random effects model is the statistic of Wald Chisquare tests, which is shown in column 3 and column 5. (4) The last three rows report the Kleibergen-Paap rk LM statistic Kleibergen-Paap rk Wald F statistic and Hansen J statistic in IV and GMM tests.

In order to ensure the robustness of our results, we substitute the share of SOEs in number with that in sales volume. The results in the second two column show that, there is no obvious difference after substitution, which indicates that our regression models are appropriate and reasonable.

Because the explanatory variables in our model are mostly macro variables, the correlations between the dependent variable and independent variables are more complicated as there might be endogeneity problems arising from simultaneity. Therefore, we use the first and second lag variables of income per capita as instruments to estimate the model; these are presented in the fifth column and are consistent with the basic regression results. We also estimate our model with generalized method of moments (GMM) and obtain similar results. The last three rows of the fifth and sixth columns report the identification test results of the instrument variables, including the underidentification test (Kleibergen-Paap rk LM test), the weak identification test (Kleibergen-Paap rk Wald F test), and the overidentification test (Hansen $\mathrm{J}$ test). The test results indicate that the first and second lag variables of income per capita are valid instrumental variables.

\section{Further tests on the role of processing trade and the SOES}

We generate an interaction variable of GDP per capita with Export Structure in the 
regression model, which represents the influence of export structure on the development of service sector after taking GDP per capita into consideration. The coefficient of the new variable is positive (see Table 3), which indicates that although processing trade has negative effects on the development of service sector, the negative effects are weaken by the regional economic development level. In other words, the higher the level of economic development in a region, the smaller the negative effects of processing trade on the development of its service sector.

Theoretically, the proportion of SOEs could have other correlations with the development of the service sector in a region. For example, as the Chinese government has emphasized the development of service sector in recent years, there are more policies to promote service development, often first implemented through SOEs. In this respect, the higher the share of SOEs, the better the development of the service sector. To deal with this problem, we add the average firm size, which could be a better proxy for state-owned economies and might not have correlations with service policies, to substitute for the share of SOEs in our regression model. The last two columns in Table 3 shows that there are no significant differences between these results and those from our original regression, which indicates that there is no difference between SOEs and private firms in their demands for producer services and that firm size matters.

Table 3 Results for alternative measures of processing trade and SOEs

\begin{tabular}{|c|c|c|c|c|}
\hline \multirow{2}{*}{ Independent } & \multicolumn{4}{|c|}{ Dependent variable } \\
\hline & \multicolumn{4}{|c|}{ Service output per capita } \\
\hline & FE & $\mathrm{RE}$ & FE & $\mathrm{RE}$ \\
\hline & $1.064^{* * * *}$ & $0.700^{* * * *}$ & $0.853^{* * * *}$ & $0.768^{* * * *}$ \\
\hline Income per capita & $(0.000)$ & $(0.000)$ & $(0.000)$ & $(0.000)$ \\
\hline Saving per capita & $-0.997^{* * *}$ & $-0.792^{* * *}$ & $-0.943^{* * *}$ & $-0.891^{* * *}$ \\
\hline & $(0.000)$ & $(0.000)$ & $(0.000)$ & $(0.000)$ \\
\hline
\end{tabular}




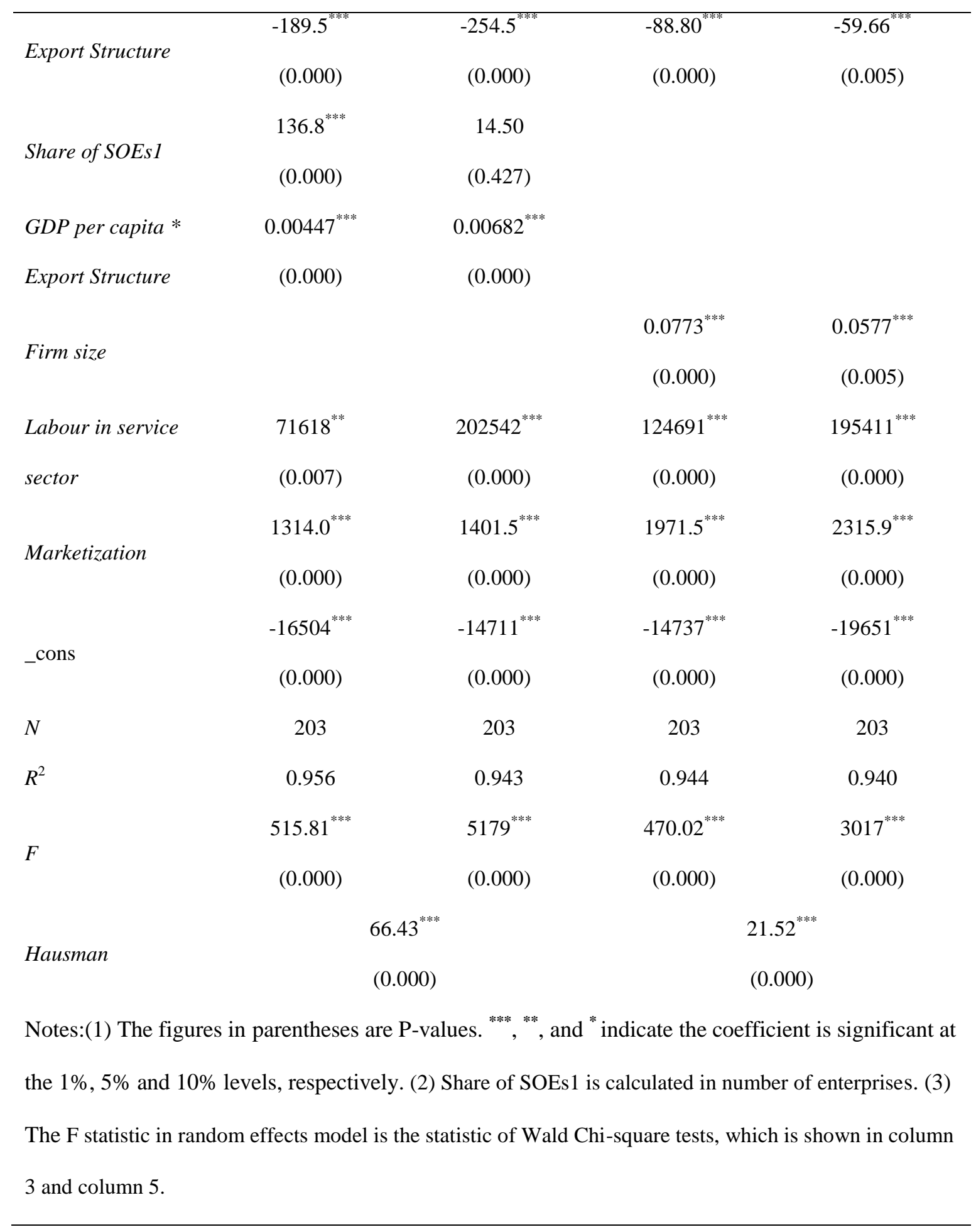

\section{Tests on specific service industries}

As shown in Table 4, we used the data of every specific service industry ${ }^{11}$ to substitute for the overall service sector data in our regression model, and found that most of the regression results are consistent with the overall regression results. It is clear that our 
regression model is reasonable and the regression results are sound.

It is worthwhile to note that, there is no significant correlation between the proportion of savings per capita and the development of wholesale and retail service and transportation, warehousing and postal service, while it is significantly negative correlated with the development of financial service. The result further confirms our theoretical analysis. The wholesale and retail service and transportation, warehousing and postal service belong to the "necessities" type of service industry" ${ }^{12}$ Therefore, consumers do not reduce the expenditure on those services even they want to save. However, the financial service industry belongs to the advanced service industry, the higher the proportion of savings per capita, the less the demand for financial services. It seems a bit strange that the regions with higher per capita savings are lower in financial service output in value added. In fact, it is stems from two aspects: on the one hand, there is a per capita income variable in our regression model, which has significant positive correlation with the financial service output variable. After controlling the income variable, the netted relationship between per capita savings and per capita financial service output is negative which is in line with the logic of our theoretical analysis.

Table 4 Results for the specific service sectors

Dependent variable: output per capita

\begin{tabular}{|c|c|c|c|c|c|c|}
\hline \multirow{3}{*}{$\begin{array}{l}\text { Independent } \\
\text { variables }\end{array}$} & \multirow{2}{*}{\multicolumn{2}{|c|}{ Financial services }} & \multicolumn{2}{|c|}{ Wholesale and retail } & \multicolumn{2}{|c|}{ Transportation, warehousing } \\
\hline & & & & & and $p c$ & services \\
\hline & $\mathrm{FE}$ & $\mathrm{RE}$ & $\mathrm{FE}$ & RE & $\mathrm{FE}$ & RE \\
\hline Income per & $0.224^{* * *}$ & $0.205^{* * *}$ & $0.166^{* * *}$ & $0.159^{* * *}$ & $0.0721^{* * *}$ & $0.0688^{* * *}$ \\
\hline capita & $(0.000)$ & $(0.000)$ & $(0.000)$ & $(0.000)$ & $(0.000)$ & $(0.000)$ \\
\hline Saving per & $-0.344^{* * *}$ & $-0.302^{* * *}$ & -0.0325 & -0.0568 & -0.00247 & -0.000293 \\
\hline
\end{tabular}




\begin{tabular}{|c|c|c|c|c|c|c|}
\hline capita & $(0.000)$ & $(0.000)$ & $(0.607)$ & $(0.380)$ & $(0.929)$ & $(0.991)$ \\
\hline Export & -5.830 & -3.090 & $-35.41^{* * *}$ & $-26.56^{* * *}$ & -4.775 & -4.528 \\
\hline Structure & $(0.352)$ & $(0.602)$ & $(0.000)$ & $(0.001)$ & $(0.181)$ & $(0.192)$ \\
\hline \multirow[b]{2}{*}{ Share of SOEs } & $21.49^{* *}$ & $20.62^{* * *}$ & 17.72 & 13.09 & -5.819 & -5.999 \\
\hline & $(0.025)$ & (0.001) & $(0.121)$ & $(0.175)$ & (0.198) & $(0.143)$ \\
\hline Labour in & $400717^{* * *}$ & $496906^{* * *}$ & $50520^{*}$ & $87452^{* * * *}$ & 10994 & $33772^{*}$ \\
\hline service sector & $(0.000)$ & $(0.000)$ & $(0.048)$ & $(0.000)$ & $(0.653)$ & $(0.086)$ \\
\hline \multirow{2}{*}{ Marketization } & $477.0^{* * *}$ & $450.0^{* * *}$ & $544.1^{* * *}$ & $642.0^{* * * *}$ & 9.856 & 12.94 \\
\hline & $(0.000)$ & $(0.000)$ & $(0.000)$ & $(0.000)$ & $(0.819)$ & $(0.750)$ \\
\hline \multirow{2}{*}{ _cons } & $-5427.2^{* * *}$ & $-5543.9^{* * * *}$ & $-3204.2^{* * *}$ & $-3674.4^{* * *}$ & $592.1^{*}$ & 487.9 \\
\hline & $(0.000)$ & $(0.000)$ & $(0.000)$ & $(0.000)$ & $(0.055)$ & $(0.129)$ \\
\hline$N$ & 203 & 203 & 203 & 203 & 203 & 203 \\
\hline$R^{2}$ & 0.879 & 0.877 & 0.837 & 0.833 & 0.778 & 0.777 \\
\hline \multirow[t]{2}{*}{$F$} & $203.4^{* * *}$ & $1713^{* * * *}$ & 144.10 & $897.5^{* * *}$ & 98.40 & $614.5^{* * *}$ \\
\hline & $(0.000)$ & $(0.000)$ & $(0.000)$ & $(0.000)$ & $(0.000)$ & $(0.000)$ \\
\hline Hausman & \multicolumn{2}{|c|}{$(0.176)$} & \multicolumn{2}{|r|}{--} & \multicolumn{2}{|r|}{$(0.438)$} \\
\hline \multicolumn{7}{|c|}{$\begin{array}{l}\text { Notes:(1) The figures in parentheses are P-values. }{ }^{* * * * * *}, \text { and }{ }^{*} \text { indicate the coefficient is significant at the } \\
1 \%, 5 \% \text { and } 10 \% \text { levels, respectively. (2) Share of SOEs } 1 \text { is calculated in number of enterprises. (3) The F }\end{array}$} \\
\hline \multicolumn{7}{|c|}{ statistic in random effects model is the statistic of Wald Chi-square tests, which is shown in column 3 , column 5} \\
\hline \multicolumn{7}{|c|}{ and column 7. (4) According to Hausman tests, random effects are preferred in the regressions on data of } \\
\hline financial servic & hd transporta & on, warehousi & and postal & ervices, and fi & fects esti & ates should be \\
\hline
\end{tabular}

In summary, our regression results show that, the income per capita in a region is positively correlated with its service development level. The lagging of China's service sector is mainly because of the lack of demand, and the reasons for the lack of demand mainly stem from an excessive tendency for national savings and a processing 
trade-oriented export structure. The demand for services by SOEs is not significantly different from that of other types of enterprises.

\section{Discussion}

Our study reveals that the development path of the service sector in developing countries is different from that in developed countries. China is a typical country characterized by its diligent and frugal people, and export-oriented policies, which has led to its unbalanced industrial structure, comprising an expanded manufacturing sector and a constricted service sector. Empirical tests reveal that a demand deficiency may be the main reason for the underdevelopment of China's service sector. More specifically, this demand deficiency stems from strong consumer preferences for saving and an export-oriented trade structure.

Most of the literature on the lagging development of China's service sector emphasizes the importance of external factors, such as statistical discrepancy (Xu 2000), institutions and policies (Cheng 2008), and access restrictions in the service industry (Jiang and Li 2004). Although some studies have noted that the processing trade structure (Jiang and Liu 2010; etc.) might hinder the development of the producer service industry, they do not conduct in-depth empirical research from the demand perspective. Our study shows that insufficient demand might be the main reason for the underdevelopment of China's service industry. In particular, previous studies have neglected the impact of consumers' high saving tendencies on the development of the service industry, which has been shown to be the main factor affecting people's demand for consumer services.

The backwardness of the service sector evident in China may also arise in other developing countries with similar consumption habits and patterns of economic development. Recently, with the increase in average manufacturing wages, more and 
more low-cost manufacturing factories have moved from China to India, Thailand, Indonesia, or Vietnam, and these may ultimately replace China as the home of the world's factories. These countries may then experience a similar development path as China in the future. Therefore, China must upgrade its manufacturing industries with advanced technologies and human capital, which will increase knowledge-intensive service input in the manufacturing production process and help promote the development of a modern service sector domestically. The "service sector and economic development deviation puzzle" in China will last for at least a while yet, but may not continue in the future.

\section{Conclusion}

The proportion of the service industry in China is significantly lower than most countries of the same income level, which is even lower than the average of that in lowand middle-income countries. Comparing the input-output tables between China, the US and India, we find that the insufficiency of consumer demand (or final demand) and producer demand (or intermediate demand) may be the main reason for the underdevelopment of the service sector in China.

We analyse the influencing factors initiating the demand insufficiency from the perspective of final and intermediate demand and perform empirical tests of our four hypotheses. These empirical tests indicate that the demand insufficiency stems mainly from the preferences of Chinese consumers for saving and China's export-oriented trade structure. Excessive saving limits consumer demand for service products and hampers the development of consumer services. The rapid development of processing trade hinders the interrelation between the domestic manufacturing and service sectors, reduces the effective demand for local producer services by the manufacturing sector, and ultimately hinders the growth of producer services. 
Based on our findings, we propose a number of suggestions for the government and different types of enterprises to promote the development of China's service sector.

First, the government should raise people's awareness about pursuing a spiritual, balanced life, in this way expanding the demand for cultural, educational, entertainment, tourism, health, and insurance services, thereby promoting the development of the consumer service industry. At the same time, the government should encourage manufacturing enterprises to optimize management and improve efficiency through servitization, in particular, by encouraging large-scale enterprises to provide service platforms for industry and small and medium enterprises (SMEs) to externalize noncore services. The government should also remove policies and subsidies that are favourable to processing trade enterprises, support the expansion of enterprises with local brands, and promote their demand for domestic $R \& D$, finance, consulting, advertising, and other producer services.

Second, the suppliers of consumer services should improve the quality of their services, provide differentiated services to groups of different ages and incomes, and promote consumer demand for service products from the perspective of improving the quality of service products. Large manufacturing enterprises should extend their business to high-value-added service industries, such as $R \& D$ and design, technical services, and marketing, and provide comprehensive services such as collaborative platforms and after-sales-service platforms for SMEs in the industry. SMEs in the manufacturing industry should enhance their core competitiveness by externalizing noncore services. Through the servitization of large enterprises and the externalization of services of SMEs, China could build a more complete manufacturing industry chain and improve the development of its service sector. 


\section{Funding}

We thank Natural Science Foundation Youth Project of Zhejiang Province (Grant No. LQ16G030014), Hangzhou Social Science Talent Youth Cultivation Program (Grant No.2016RCZX38) and the Ningbo Talent Training Project (Grant No. NBLJ201802005) for funding.

\section{Notes}

1. World Bank: World Development Index 2015.

2. China Statistics Bureau: China Statistical Yearbook 2015.

3. OECD: The World Input-Output Database.

4. Demand here includes final consumption demand and intermediate input demand.

5. We divide the output of every service industry into two parts, final consumption by consumers and intermediate input by companies of different industries. Therefore, the share of consumption demand is equal to the ratio of final consumption of one service industry to the total output of the service industry. For example, consumers might purchase transportation service for themselves, which is called the final consumption; companies might purchase transportation service for their business, which is called the intermediate input. The total output of transportation industry is either used for final consumption or for intermediate input.

6. The share of service inputs is the ratio of service inputs to total intermediate inputs of manufacturing industries. In order to produce products, it is necessary to input different kinds of materials or services, which are called intermediate inputs.

7. According to Coffey and Bailly (1991), services comprises R\&D, designing, advertising and marketing.

8. See: The comparisons in the Introduction section of this paper.

9. The output of the service sector is in terms of value-added. Many studies prefer to use the percentage share of the service sector to GDP to measure the development of service sector, which places the variable in a closed number system. There are also conceptual problems in using percentages. For example, the percentage share of the service sector in China is low because the share of manufacturing is so high. Fortunately, we can eliminate the earlier number problem and this manufacturing effect using per capita values instead of percentages. We would like to thank an anonymous reviewer for this advice.

10. Most literature, such as Jiang and Liu (2010), took the proportion of processing trade to GDP as the level of processing trade, while which reflects the trade level of a region rather 
than the trade structure. We employ the proportion of the export of foreign-invested enterprises to the total export to denote the trade structure, which more accurately expresses the connotation of this variable.

11. The specific service industries here comprise three categories, namely, financial services, wholesale and retail services, transportation, warehousing and postal services.

12. "Necessity" means that it is necessary to use those services to make transactions in our daily life.

\section{References}

Bai, C.E., and L.X. Xu 2005. Incentives for CEOs with multitasks: Evidence from Chinese state-owned enterprises. Journal of Comparative Economics 33(2):517539. doi: 10.1016/j.jce.2005.03.013

Barcet, A., J. Bonamy, and A. Mayere. 1983. Economie de services aux entreprises economie et humanisme [Economics of business services economics and humanism]. Lyon: University of Lyon.

Baumol, W.J. 1967. Macroeconomics of unbalanced growth: The anatomy of urban crisis. American Economic Review 57: 415-426. doi: 10.4236/me.2011.23028

Bell, D. 1974. The coming of post-industrial society. London: Heinemann Educational Books Ltd. doi: 10.1080/00131727609336501

Beyers, W.B., and D.P. Lindahl. 1996. Explaining the demand for producer services: Is cost-driven externalization the major factor. Regional Science 75: 351-374. doi:10.1111/j.1435-5597. 1996.tb00669.x

Buera, F., and J. Kaboski. 2012. The rise of the services economy. American Economic Review 102(6):2540-2569. doi: 10.1257/aer.102.6.2540

Cheng, D. 2013.The development of the service industry in the modern economy: Mechanisms and implications for China. China Finance and Economic Review 1(1):1-12. doi: 10.1186/2196-5633-1-3

Cheng, D. 2008. Development level, structure, and impact of producer services in China. Economic Research Journal 1:76-88.

Chenery, H.1960. Patterns of industrial growth. American Economic Review 50(4):624654. doi: $10.2307 / 1910137$

Clark, C. 1940. The conditions of economic progress. London: MacMillan\&Co. Ltd. 
Coffey, W.J., and A.S. Bailly. 1991. Producer services and flexible production: An exploratory analysis. Growth and Change 22(4):95-117. doi: 10.1111/j.14682257. 1991.tb00564.x

Daniels, P.W. 1998. Economic development and producer services growth: the APEC experience. Asia Pacific Viewpoint 39(2):145-159. doi:10.1111/14678373.00060

Dehejia, R., and A. Panagariya.2016. The link between manufacturing growth and accelerated services growth in India. Economic Development and Cultural Change 64(2):222-263. doi: 10.1086/683842

Eichengreen, B., and P. Gupta. 2013. The two waves of service sector growth. Oxford Economic Papers 65 (1): 96-123. doi: 10.1093/oep/gpr059

Eichengreen, B., and P. Gupta. 2011. The service sector as India's road to economic growth. NBER Working Paper No.16757. doi: 10.3386/w16757

Fisher, A.G.B. 1939. Primary, secondary and tertiary production. Economic Record. 15: 24-38. doi: 10.1111/j.1475-4932. 1939.tb01015.x

Francois, J. 1990. Producer services, scale, and the division of labour. Oxford Economic Papers 42: 715-729. doi: 10.1093/oxfordjournals.oep.a041973

Francois, J., and J. Woerz. 2008. Producer services, manufacturing linkages, and trade. Journal of Industry, Competition and Trade 8:199-229. doi: 10.1007/s10842008-0043-0

Fuchs, V.R. 1968. The Service Economy. Cambridge: National Bureau of Economic Research, Inc.

Galbraith, J.K. 1967. The new industrial state. Boston: Princeton University Press.

Gershunny, J. 1978. After industrial society? The emerging self-service economy. London: Macmillan.

Grubel, H.G., and M.A. Walker. 1989. Modern service sector growth: Causes and effects. Montreal: Fraser Institute.

Guerrieri, P., and V. Meliciani. 2005. Technology and international competitiveness: The interdependence between manufacturing and producer services. Structural Change and Economic Dynamics 16(4): 489-502. doi: 10.1016/j.strueco.2005.02.002

Jiang, X., and H. Li. 2004. Service industry and China's economy: Correlation and potential of faster growth. Economic Research Journal 1:4-15. 
Jiang, J., and Z. Liu. 2010. Can orientation to factory of the world promote China's producer service development. Economic Theory and Business Management 3: 62-68. doi: 10.3969/j.issn.1000-596X.2010.03.010

Kuznets, S. 1953. Shares of upper income groups in income and savings. Cambridge: National Bureau of Economic Research.

Kuznets, S. 1955. Economic growth and income inequality. American Economic Review 45(1): 1-28. doi: 10.1086/257662

Liu, M., M. Rui., and K. Yao. 2010. Co-evolution between producer service embedded in value chain and industrial upgrade of manufacturing. China Industrial Economics 8: 66-75. doi: 10.19581/j.cnki.ciejournal.2010.08.007

Lu, Z., Y. Liu, and Q. Wang. 2006. Strategy selection of China's producer services industries development -Based on the view of industrial interaction. China Industrial Economy 8: 5-12. doi: 10.19581/j.cnki.ciejournal.2006.08.001

Peng, Z.L. 2001. Proportion of China 's tertiary industry- From the perspective of international comparison. Statistical Research 3:22-27. doi: 10.19343/j.cnki.111302/c.2001.03.004

Schettkat, R., and L. Yocarini. 2006. The shift to services employment: A review of the literature. Structural Change and Economic Dynamics 17(2):127-147. doi: 10.1016/j.strueco.2005.04.002

Walker, R. 1985. Is there a service economy? The changing capitalist division of labour. Science and Society 49 (1): 42-83. doi: 10.1002/9780470755716.ch6

Wang, D., Z. Zhang, and C. Bai. 2007. Size of government, rule of law and the development of service sector. Economic Research Journal 6:51-64,118.

Wang, X.L., G. Fan., and J.W. Yu. 2016. Marketization index of China's province: NERI Report 2016. Beijing: Social Science Academic Press.

Wolf, A. 2005. The service economy in OECD countries, STI Working Paper, No.03, OECD, Paris. doi: 10.1787/9789264010307-4-en

Wu, Y.R. 2015. China's service sector: The new engine of economic growth. Eurasian Geography and Economics 56(6):618-634. doi: 10.1080/15387216.2016.1153429

Xiao, W., and W.J. Fan. 2012. Measurement of the paradox of China's service sector growth-research based on "two waves" pattern. Economists. 7: 88-95. Doi: 10.16158/j.cnki.51-1312/f.2012.07.012 
Xu, X.C. 2000. An analysis of the reasons for the lagging behind of China 's service industry in the 1990s. Management World 6 :73-77. doi: 10.19744/j.cnki.111235/f.2000.06.009

Ye, D. 2008. The explanation of the behaviour of East Asia's countries' high saving and low consumption from the viewpoint of economics. Asia-Pacific Economic Review 3:15-18. doi: 10.16407/j.cnki.1000-6052.2008.03.017

Zheng, J.H., L. Zhang., and Y. Wang. 2011. The underdevelopment of service industry in China: An empirical study of cities in Yangtze River Delta. Frontiers of Economics in China 6: 413-446. doi: 10.1007/s11459-011-0140-6

\section{Appendix}

Table A1 Share of final consumption expenditure in service sector (India, China, and the US)

\begin{tabular}{|c|c|c|c|c|c|c|c|}
\hline Service sector & India & China & US & Service sector & India & China & US \\
\hline \multicolumn{8}{|l|}{ Wholesale and retail } \\
\hline \multirow[t]{2}{*}{ trade; repairs } & $34.61 \%$ & $12.38 \%$ & $54.25 \%$ & Computer and related activities & $18.07 \%$ & $1.89 \%$ & $3.32 \%$ \\
\hline & & & & R\&D and other business & & & \\
\hline \multirow[t]{2}{*}{ Hotels and restaurants } & $52.96 \%$ & $24.86 \%$ & $78.32 \%$ & activities & $10.45 \%$ & $12.31 \%$ & $8.76 \%$ \\
\hline & & & & Public administration and & & & \\
\hline \multirow[t]{2}{*}{ Transport and storage } & & & & defence; compulsory social & & & \\
\hline & $47.30 \%$ & $8.40 \%$ & $25.70 \%$ & security & $100.12 \%$ & $98.29 \%$ & $91.38 \%$ \\
\hline \multicolumn{8}{|l|}{ Post and } \\
\hline telecommunications & $26.99 \%$ & $27.80 \%$ & $45.85 \%$ & Education & $98.22 \%$ & $83.07 \%$ & $90.88 \%$ \\
\hline \multicolumn{8}{|l|}{ Financial } \\
\hline intermediation & $32.04 \%$ & $23.27 \%$ & $40.15 \%$ & Health and social work & $97.29 \%$ & $84.46 \%$ & $97.85 \%$ \\
\hline \multirow{2}{*}{ Real estate activities } & & & & Other community, social and & & & \\
\hline & $98.33 \%$ & $42.19 \%$ & $71.58 \%$ & personal services & $51.70 \%$ & $38.21 \%$ & $69.71 \%$ \\
\hline \multicolumn{8}{|l|}{ Renting of machinery } \\
\hline and equipment & $113.22 \%$ & $6.58 \%$ & $32.62 \%$ & Average & $53.79 \%$ & $34.42 \%$ & $58.86 \%$ \\
\hline
\end{tabular}


Table A2 Service inputs in total intermediate inputs of different manufacturing industries

\begin{tabular}{|c|c|c|c|}
\hline Manufacturing Sectors & India & China & $\mathbf{U S}$ \\
\hline Mining and quarrying & $36.52 \%$ & $23.11 \%$ & $36.66 \%$ \\
\hline Food products, beverages and tobacco & $26.90 \%$ & $15.71 \%$ & $34.01 \%$ \\
\hline Textiles, textile products, leather and footwear & $39.09 \%$ & $18.80 \%$ & $51.94 \%$ \\
\hline Wood and products of wood and cork & $33.63 \%$ & $13.96 \%$ & $34.87 \%$ \\
\hline Pulp, paper, paper products, printing and publishing & $28.35 \%$ & $16.56 \%$ & $42.55 \%$ \\
\hline Coke, refined petroleum products and nuclear fuel & $18.36 \%$ & $13.18 \%$ & $20.51 \%$ \\
\hline Chemicals and chemical products & $25.48 \%$ & $17.97 \%$ & $35.03 \%$ \\
\hline Rubber and plastics products & $22.12 \%$ & $13.02 \%$ & $32.32 \%$ \\
\hline Other non-metallic mineral products & $27.35 \%$ & $17.80 \%$ & $40.85 \%$ \\
\hline Basic metals & $18.40 \%$ & $12.58 \%$ & $24.69 \%$ \\
\hline Fabricated metal products & $21.11 \%$ & $12.38 \%$ & $28.63 \%$ \\
\hline Machinery and equipment, nec & $23.11 \%$ & $15.23 \%$ & $27.57 \%$ \\
\hline Computer, Electronic and optical equipment & $36.40 \%$ & $21.15 \%$ & $39.99 \%$ \\
\hline Electrical machinery and apparatus, nec & $22.15 \%$ & $16.35 \%$ & $25.04 \%$ \\
\hline Motor vehicles, trailers and semi-trailers & $22.67 \%$ & $12.75 \%$ & $21.62 \%$ \\
\hline Other transport equipment & $22.36 \%$ & $10.87 \%$ & $27.49 \%$ \\
\hline Manufacturing nec; recycling & $46.67 \%$ & $16.92 \%$ & $42.64 \%$ \\
\hline Electricity, gas and water supply & $31.24 \%$ & $16.39 \%$ & $40.78 \%$ \\
\hline Construction & $22.27 \%$ & $21.28 \%$ & $31.63 \%$ \\
\hline Average & $27.59 \%$ & $16.11 \%$ & $33.62 \%$ \\
\hline
\end{tabular}

